\title{
Katharina Pistor* \\ The Code of Capital: How the Law Creates Wealth and Inequality - Core Themes
}

https://doi.org/10.1515/ael-2020-0102

Published online February 12, 2021

Abstract: In this brief introduction, I summarize the core themes of my book "The Code of Capital: How the Law Creates Wealth and Inequality”. Capital, I argue, is coded in law - predominantly in a handful of private law institutions. By relying on legal coding techniques, asset holders invoke the right to enforce claims against others, if necessary with the help of the state's coercive power.

Keywords: Capital, private law, the legal profession, global capitalism

JEL Classification: L21, L22, P10, P12, P14, P16

\section{Table of Content}

1 The Code of Capital: Core Themes

References

\section{Katharina Pistor's The Code of Capital: A Symposium}

1. The Code of Capital: How the Law Creates Wealth and Inequality - Core Themes, by Katharina Pistor, https://doi.org/10.1515/ael-2020-0102.

2. Three Projects in the New Law and Finance, by Dan Awrey, https://doi.org/10.1515/ael-20200069.

3. The Laws of Knowledge, Knowledge of Laws: A “Political Epistemology” Perspective on Pistor's The Code of Capital, by Lisa Herzog, https://doi.org/10.1515/ael-2020-0064.

4. The Political Economy of Private Law: Comment on 'The code of capital - how the law creates wealth and inequality', by Matthias Thiemann, https://doi.org/10.1515/ael-2020-0077.

5. Capitalization and its Legal Friends, by Leon Wansleben, https://doi.org/10.1515/ael-20200063.

6. Theorizing Beyond “The Code of Capital”: A Reply, by Katharina Pistor, https://doi.org/10. 1515/ael-2020-0101.

Princeton University Press (2019)

*Corresponding author: Katharina Pistor, Law School, Columbia University, New York, USA, E-mail: kpisto@law.columbia.edu 


\section{The Code of Capital: Core Themes}

I would like to thank the editors of Convivium for putting together this special issue and for inviting me to write a reply to the critiques in this issue. My hope was to write a book about capital that would open fresh perspectives and also engage readers from different disciplinary backgrounds. Having the opportunity to engage scholars from philosophy, law, sociology and business/accounting is a wonderful reward for such an undertaking. Thanks also to the contributors who read the book and put their thoughts and their critiques in writing. In what follows, I will summarize the core themes of my book with only scant reference to their critiques, which I reserve for the reply at the end of this issue.

Capital is not a thing, but a social relation, as Marx taught us (Marx, 1974) according to Marxists, the relation between capital and labor as at the heart of this relation. Ownership over the means of production allows capitalists to extract surplus from labor, which they can feed back into the production and surplus creation process, or take out for consumption. Law figures in this story, but as part of the super-structure, not its basis. Only the "old" institutional economists, foremost among them John Commons, gave law a central role in explaining capitalism (Commons, 1924). This book owes much to their writings and to the legal realists, as it does do social theorists like Karl Polanyi who sought to understand the long arch of historical transformations by observing the details that link societies to markets, social to economic and ultimately political change (Polanyi, 1944).

Capital, I argue in my book, is indeed a social relation, but one that is organized around and mediated by the state and its coercive powers, which have been institutionalized as law. Law is often depicted as a vertical relation between a state and the subject it controls, the people and organizations that occupy its territory. For social and economic activities, there is, however, another dimension of law, namely private law. The distinction between public and private law belongs to the modern period and is more pronounced in some legal systems than in others. It reflects an increasing differentiation of governance tasks and mechanisms for ever more complex social organizations. Several contributors to this issue have criticized this book for not saying enough about public law, a point to which I will return in my reply. For now, suffice to say that the legal domain that in my view has remained largely hidden from view in the discussion of social change, has been private law. It has been naturalized and reified and the fact that it owes its power of social ordering ultimately to the state is often ignored.

Private law consists of legal arrangements that allow private parties to organize their horizontal relations while resting assured that these arrangements will 
(in all likelihood) be enforceable in a court of law. Private actors may trade, invest, or gamble without this assurance, but they would have to protect themselves against possible breach or interference by strangers to their transactions and the social groups within which they take place. They would have to carefully select and monitor their counterparties or middlemen, wall in their properties, hire private guards, and so forth (Kronman, 1985; Landa, 1981). To be sure, modern technologies have greatly reduced the cost of self-help. As a result, the relative importance of coercive law enforcement (and thus of states) may decline. In the book, I argue that the digital code is unlikely to replace the legal code any time soon; and moreover, that the decisions that digital coders make are not fundamentally different from legal coders. Still, while writing the book, I did not fully grasp the potential of digital coding and of data, an issue I have since taken up (Pistor, 2020a, 2020b).

Setting aside the promises and challenges of the digital code, a critical premise of my argument is that for social relations to scale beyond the size of social groups that can rely on self-monitoring, something else is needed: a powerful agent with the authority to verify the rules that can enforce promises and uphold property rights, if necessary with the help of coercive power (Hodgson, 2009; Weber, 1968). Private law enables private parties to avail themselves of the state's coercive powers in organizing their social and economic relations well beyond tightly knit spheres of exchange, while enjoying considerable flexibility in doing so. This is key for turning simple objects, promises and ideas or knowhow (or assets) into capital, that is, into assets that create new and secure past wealth. Deciphering the role that private law plays in the making of capital is the book's core mission.

The basic argument the book makes is fairly simple: With the right legal coding any object, promise or idea can be turned into a capital asset. The process of coding capital bestows its holders with legal attributes that greatly enhance the likelihood that they will produce and secure wealth. I identify four attributes, namely priority, durability, universality, and convertibility. Priority means that some asset holders enjoy stronger rights than others; these rights can be extended in time by protecting them against other claims, thereby lending them durability and allowing capital to grow. Holders of financial asset attain durability by way of convertibility, an option to swap privately into state issued legal tender that maintains its nominal value (Ricks, 2016), and thereby to lock in past gains. Last but not least, universality ensures that all have to yield to these legal rights, whether or not they knew about them. Coding capital then is the process of grafting priority, durability or convertibility, and universality on to different types of assets and thereby creating wealth for their holders and inequality for the rest.

Only a handful of institutions of private law are needed to turn a simple asset into capital. For priority, property and collateral law do most of the work; and for 
durability, trust and corporate law. Bankruptcy is in the mix, because, even though it is mandatory and as such less malleable, it sanctions priority rights that were created outside bankruptcy. Owners of assets that are in the possession of a defaulting debtor can retrieve them, and holders of collateral interests can enforce against them before any other creditors. Claimants at the end of the queue get only the leftovers. The legal modules that confer priority and durability operate by design against anybody; in contrast, contract law is a legal relationship that binds only two parties to the contract. Still, contract law occupies an important role in the coding of capital, because contractual relations enjoy legal protection against outside interference. Moreover, with the help of information technology, the costs of contracting can be reduced to a point that contractual relations can be universalized - simply by requiring millions of platform users to click "agree" and thereby sign on to the same contract that bind everybody else. To be clear, these six modules are not the only legal devices that can be used for coding capital, but they have been central for coding of capital over the past four hundred years or so. The book applies this framework to the coding of land, firms, debt, and knowhow. While land came first, the story unfolds not in chronological order. In other words, there is no explicit or implied argument about historical stages of the coding of capital.

To me, one of the most striking discoveries was the persistence and versatility of the modules of the code. Property rights, as Bernard Rudden reminds us, first emerged during the age of feudalism (Rudden, 1994). The same legal modules, property rights, collateral as well as trust law, which were used to code land are used today for coding securitized assets and complex financial derivative structures. The legal modules are not entirely static; they were adapted to changing circumstances. Property rights in land evolved from an integral part of the feudal socio-political order into a legal right held by individuals in principle irrespective of their social status. I say "in principle", because endowment effects limited access to land and other assets long after legal restrictions had been lifted and gave the privileged landowners a head-start over everyone else. The importance of land as the primary source of wealth prior to the onset of industrialization, and indeed of capitalism, is also evident in the evolution of trust last. Well into the nineteenth century, land was the only asset that could be conveyed to a trust, with sovereign debt and shares in the English East Indian Company allowed only later. Today, virtually anything that can generate future cash flows can be thrown behind the veil of a trust thereby granting investors (the beneficiaries) privileged access to these cash flows. In addition, the fiduciary duties of trustees have been relaxed, leading one student of trust law to talk of the "stripping of the trust" (HofriWinogradow, 2015), and beneficiaries have turned their equitable interests against the trust into fixed income claims. 
These modifications notwithstanding, I stress continuity of the legal modules over change, because their basic structure remained intact even as they were adapted to new assets and changing circumstances. Still, there might room for another book that tells the story of each module over time, and preferably, in comparative perspective. In fact, I first thought about organizing the book around the legal institutions (property, trust, corporate law etc.), rather than the assets (land, firms, debt, knowhow) they have coded as capital. It might have been a great book for legal historians, but probably would have not conveyed the power of the legal code and its impact on the creation of wealth and inequality for a broader readership. Yet, analyzing the patterns of legal change in greater detail will be an important aspect for further deepening the theoretical analysis and drawing out the implications of "The Code of Capital" for social and political theory (more on this in the reply).

Placing private law at the center of the analysis seems to disregard the rise of global capitalism. Private law is domestic law; only some aspects of private have been harmonized globally. Even the EU, which had aspired to creating a comprehensives set of common rules for a common market, eventually switched direction. In lieu of a common set of substantive rules, say for contract, corporate law, etc., member states have harmonized the rules that determine which country's rules should apply in cross-border cases where more than one legal system is in play. In legal jargon, these are the "conflict-of-law rules" (or international private law), which are part of the domestic legal orders of every country. These rules stipulate separately for every legal domain the factors that should determine whose law applies: the location of an asset for property rights, a company's headquarters or place of incorporation for corporate law, or simply party choice for contract law - and increasingly for other areas of the law as well.

They may look arcane or unassuming, but these rules have been instrumental for the integration of economic and financial systems globally. In the absence of a global state and a global law, conflict-of-law rules have been used to extend the reach of domestic law beyond the territorial borders of the states from which it originated. Creating a menu of legal systems for private agents to choose from when organizing their transnational relations required at least two things: Different rules with some legal systems offering greater advantages for the coding of capital than others; and the willingness of states with less desirable rules to enforce the selected rules within their territories. The first condition is easy to meet, as legal rules do in fact vary across countries and legal system. More interestingly, they do so fairly systematically, with the common law offering for the most part superior conditions than do most civil law systems. Comparing civil law and common law regimes has a long trajectory, including more recently the law and finance literature (La Porta, Lopez-de-Silanes, Shleifer, \& Vishny, 1998). I don’t 
add much to this debate other than suggesting that the organization of the legal profession, the role of private attorneys and courts in the legal system, has not received the attention it deserves.

The second condition, i.e. other states willing to enforce foreign law in their courts, requires a bit more explanation. Here, we have seen a shift over the past several decades towards allowing private parties to freely choose the law from among different legal systems that best suits their needs. Some states did so on their own behest; others were pushed by economic and legal integration projects, such as the European Union. Either way, the timing is conspicuous: it overlaps with the integration of financial markets globally since the late 1980s and early 1990s. Teasing out the interaction between decisions to remove capital controls, to privatize financial intermediaries and allow for the free movement of capital and changes in conflict-of-law rules certainly deserve further research.

When using the lens of the code of capital, global capitalism does not appear as some "supra-national" system that is detached from states or state law or that has diminished the role of states. Instead, global capitalism is rooted in select legal systems that have accommodated capital for centuries and that today are home to the major players in global finance, as well as the 100 top global law firms. English law has dominated international trade for centuries, with the direction of causality possible running from empire to legal dominance, but equally possible in the opposite direction. Today, English and New York state law dominate the coding of financial capital that is traded globally. These two jurisdictions are the rule makers for global capital. Most other jurisdictions will recognize and enforce the legal rights they create; they are rule takers. By recognizing and enforcing foreign law in their courts, they extend universality way beyond the territory of the country to provide the critical modules of the code.

Capital and the system to which it has given its name was not designed by anybody in a coherent fashion, but neither can it be described as the product of natural evolution. To turn a simple object, promise or idea into capital, somebody must decide, which and whose assets shall be coded as capital; others must accept the coding, even yield to it. And should the coding be challenged, someone must decide, whether a strategy should be upheld, struck down, or changed. These tasks are taken up by different agents: asset holders, lawyers, courts, regulators, and legislatures; and not just agents that all belong to the same state, but are dispersed among several. The de-centering and diffusion of state power through private law and conflict-of-law rules, the book suggests, is critical for understanding a system that is at once built from state law and difficult to constrain through collective governance mechanisms of states. This might help explain, why there is no simple reform strategy. In the book, I therefore propose a strategy of incremental change aimed at scaling back the mechanism that have contributed to the diffusion of state 
power and their concentration in private hands. To several critics this strategy is unsatisfactory. I don't disagree and my own thinking has evolved since the book went to press, especially since the economic fallout from COVID-19 pandemic, which might create an opportunity for more radical change. Still, the measures I discuss in the book are in my mind and indispensable for creating the needed space for retooling state power.

\section{References}

Commons, J. R. (1924). The legal foundations of capitalism. New York: The MacMillan Company. Hodgson, G. M. (2009). On the institutional foundations of law: The insufficiency of custom and private ordering. Journal of Economic Issues, 43(1), 143-166.

Hofri-Winogradow, A. S. (2015). The Stripping of the trust: A study in legal evolution. ssrn.com. https://doi.org/10.3138/utlj.2325.

Kronman, A. T. (1985). Contract law and the state of nature. Journal of Law, Economics, and Organization, 1, 5-32.

La Porta, R., Lopez-de-Silanes, F., Shleifer, A., \& Vishny, R. W. (1998). Law and finance. Journal of Political Economy, 106(6), 1113-1155.

Landa, J. T. (1981). A theory of the ethnically homogeneous middleman group: An institutional alternative to contract law. Journal of Legal Studies, 10, 349-362.

Marx, K. (1974). Das Kapital. London: Lawrence and Wishart.

Pistor, K. (2020a). Rule by data: The end of markets?. forthcoming. Journal of Contemporary Problems (special issue).

Pistor, K. (2020b). Statehood in the digital age. Constellations, 27(3), 3-18.

Polanyi, K. (1944). The great transformation: The political and economic origins of our time. Boston: Beacon Press.

Ricks, M. (2016). The money problem. Chicago: University of Chicago Press.

Rudden, B. (1994). Things as things and things as wealth. Oxford Journal of Legal Studies, 14(1), 81-97.

Weber, M. (1968). Economy and society: Outline of interpretive sociology. California: University of California Press. 